\title{
Bioefficacy of paclobutrazol on growth, flowering, fruiting and yield attributes of mango cv. Dashehari under Pantnagar agro-climatic condition
}

\section{K Kumar, JS Gora \& CP Singh}

Journal of Agriculture and Ecology

Volume-7 (June, 2019)

ISSN: $2456-9410$

\section{Journal of Agriculture \\ and Ecology}

ISSN: 2456-9410

Volume: 7

Journal of Agriculture and Ecology (2019) 7: 27-37

http://doi.org/10.53911/JAE.2019.7103

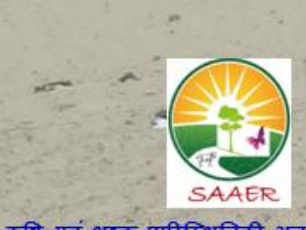

कृषि एवं शुष्क पारिस्थितिकी अनुसंधान सोसाइटी

Society for Agriculture and Arid Ecology Research

Bikaner (Rajasthan) INDIA-334006

Website: www.saaer.org.in

Email: saaeriae2016@gmailicom 
Bioefficacy of paclobutrazol on growth, flowering, fruiting and yield attributes of mango cv. Dashehari under Pantnagar agro-climatic condition

\author{
K Kumar $\searrow^{1 \#}$, JS Gora ${ }^{2} \&$ CP Singh ${ }^{3}$ \\ ${ }^{I}$ Department of Horticulture, College of Agriculture, GBPUAT, Pantnagar -263 145, Uttarakhand, India \\ ${ }^{\#}$ Current address: Scientist (Hort.-Fruit Science), Division of Crop Improvement, ICAR-CIAH, Bikaner- \\ 334006, Rajasthan India \\ ${ }^{2}$ Scientist (Hort.-Fruit Science), Division of Crop Production, ICAR-CIAH, Bikaner-334006, Rajasthan \\ India \\ ${ }^{3}$ G.B.Pant University of Agriculture and Technology, Pantnagar -263 145, Uttarakhand, India \\ DC Corresponding author: K Kumar, Email: kamlesh9520@gmail.com
}

\section{Article Info}

Article history

Received: 05 March 2019

Accepted: 15 May 2019

Available online: 15 June

2019

Key Words: Bioefficacy, paclobutrazol, Mango, Dashehari, regular bearing.

\begin{abstract}
The investigation was carried out to find out the bioefficacy of paclobutrazol on regular bearing of mango cv. Dashehari. Paclobutrazol was applied as soil drench around the tree trunk @ 15ml, 20ml, 25ml, 30ml, $35 \mathrm{ml}, 60 \mathrm{ml}$ and $30 \mathrm{ml}(\mathrm{ES}) /$ tree along with control. There was significant variations observed in growth, flowering, fruiting, yield and quality attributes due to different doses of paclobutrazol. Treatment $T_{4}$ (paclobutrazol 30ml/tree) was found superior with respect to yield and quality parameters. It was found to reduce vegetative growth and increase flowering, fruit set, fruit retention, yield attributes, TSS, sugars, ascorbic acid and $\beta$ carotene content. Therefore, it is finally recommended that paclobutrazol@30 ml/ tree should be applied for getting maximum fruit yield without affecting the fruit quality.
\end{abstract}

Copyright (02019 Kumar et al., This is an open access article published under the terms of the Creative Commons Attribution License, which permits unrestricted use, distribution, and reproduction in any medium, provided the original work is properly cited.

Preferred citation: Kumar K, Gora JS \& Singh CP. 2019. Bioefficacy of paclobutrazol on growth, flowering, fruiting and yield attributes of mango cv. Dashehari under Pantnagar agro-climatic condition. Journal of Agriculture and Ecology, 7: 27-37; http://doi.org/10.53911/JAE.2019.7103.

\section{Introduction}

Mango (Mangifera indica L.) is the most popular fruit in the tropical and subtropical regions of the world and acknowledged as 'King of fruits' in India owing to its religious and social importance, delicious taste, capitative flavour, attractive aroma and diverse end uses. Currently, mango is produced in more than 90 countries worldwide. India's share in the world's mango production is around 56 per cent (Kumar 2015; Anusuya et al. 2018). India ranks firsts in area and production of mango in the world. Mangoes are generally induced to flower during October to December in the northern hemisphere and during June- August in southern hemisphere. However, irregularity of 
flowering in mango, which varied in the time and intensity of flowering from year to year to almost complete biennial (alternate) flowering habit, is not an uncommon phenomenon. Accordingly, the un-raveling of the nature of flower triggering and signaling elements is of utmost significance if further improvement in mango fruit trees production is to be achieved (Narvariya et al. 2015; Kumar et al. 2016). It occupies the largest chunk of fruit acreage, but it is well admitted that our present level of production is not sufficient enough. Successful mango cultivation is best with many intricate problems like biotic and abiotic stresses viz., mango malformation, alternate bearing, physiological disorders, erratic bearing under erratic weather situations etc. (Gora et al. 2017). Most of the North Indian varieties viz. Dashehari, Langra, Chausa, Bombay Green are alternate bearer, while, most of the South Indian varieties bear regularly (Pandey \& Dinesh 2010). Use of plant growth regulators offer great scope for higher production as one of the recent development in the field of scientific horticulture, because most of the physiological processes of plant can be modified through the application of plant growth regulators (Bagel et al. 2004). The critical review of the existing knowledge reveal that flowering in mango is on terminals and therefore, after harvest the plant should put up new vegetative growth which must physiologically mature before the flower bud differentiation period. To achieve this, influence of gibberellins in growing shoots will have to be checked for flowering in following season (Singh \& Ranganath 2006). Use of Paclobutrazol, a potent plant growth retardant, has opened a new era in mango production. The first report about the use of paclobutrazol (cultar) on mango came from India where concentrations of 1.25 to 10 $\mathrm{g}$ a.i. per tree in the cultivars Dashehari and Banganpalli were tested (Kulkarni 1998). Cultar is a chemical growth retardant which retards the endogenous synthesis of gibberellins, has proved to be promising for flower initiation in shoot bud, giving early and profuse flowering subsequently increases fruit yield regularly in alternate bearing cultivars viz., Alphonso, Chausa, Dashehari and Langra (Pandey \& Dinesh 2010). This chemical is being widely used for regulation of bearing in commercial cultivars of mango. It reduces shoot elongation and promotes flowering (Kulkarni 1988; Burondkar \& Gunjate 1991). Therefore, an attempt was made to find out the bioefficacy of paclobutrazol on regular bearing of mango cv. Dashehari.

\section{Materials and methods Experimental site and condition}

The experiment was conducted at Horticulture Research Center, Patharchatta of G.B. Pant University of Agriculture \& Technology, Pantnagar, Udham Singh Nagar, Uttarakhand. The Center is located at $29^{\circ}$ North latitude, $79.3^{\circ}$ East longitude and at an altitude of 243.84 meters above mean sea level. The climate of Pantnagar is characterized by humid subtropical with dry and hot summer and cold winters. The maximum temperature ranging from $30^{\circ} \mathrm{C}$ to $43^{\circ} \mathrm{C}$ in summer and minimum from $5^{\circ} \mathrm{C}$ to $10^{\circ} \mathrm{C}$ in winter. The annual rainfall is 1400 $\mathrm{mm}$. Monsoon occurs from the third week of June to the middle of September. July and August are the wettest months (mean rainfall 
350-425 mm per annum). Frost can be expected from the last week of December to middle of February. Occasionally light rains are expected during winter.

\section{Experimental material design, treatment and layout}

The investigation was carried out on uniform mango trees (25 years) of cultivar Dashehari. All the treatments were replicated thrice. The total number of plants under experiment was 48. The experiment was laid out in randomized block design. Paclobutrazol was soil drenched to the selected mango trees @ 15ml, 20ml, 25ml, 30ml, 35ml, 60ml, 30ml (ES) dissolved in 5 litres of water per tree along with control. The application area of each treated trees kept wet by providing 5-6 litres of water at 10-15 days intervals for about two months. There were 8 treatments replicated thrice in randomized block design.

\section{Observations}

\section{Vegetative and reproductive growth parameters}

For recording vegetative and flowering characters 10 shoots were selected randomly in all directions of tree and data from these shoots along with tree were recorded. Vegetative growth parameters viz. tree height, trunk girth, tree spread, shoot length, leaf area and number of leaves per shoot etc was recorded. Reproductive parameters such as number of male flower, hermaphrodite flower, sex ratio, fruit set, fruit retention $(\%)$ and fruit drop $(\%)$ were recorded on tagged shoots.

\section{Fruit parameters}

The fruits were harvested from each tree under experiment on $16^{\text {th }}$ of June. All the fruits from the individual tree were picked manually and collected under the trees and number of fruits per tree and fruit yield per tree was recorded. The total weight of the marketable fruits per tree was recorded using a pan balance of $5 \mathrm{~kg}$ capacity. The data were expressed in $\mathrm{kg}$ per tree.

\section{Physico-chemical parameters}

A representative sample of $2 \mathrm{~kg}$ fruits/ tree was taken randomly from all directions of the tree and various physico-chemical parameters (fruit weight, length, width, volume, specific gravity, peel, pulp, stone weight, TSS, titrable acidity, ascorbic acid, total sugars, reducing and non-reducing sugars and $\beta$ carotene content etc) were recorded.

\section{Statistical Analysis}

The data were statistically analyzed for analysis of variance with the help of computer using RBD, (Sendicor \& Cochron 1987). The significance of variance was observed by applying ' $\mathrm{F}$ ' test and critical difference was calculated at 0.05 level of probability.

\section{Results and Discussion}

The results (Table 1) revealed that tree height, tree girth and tree spread were not affected significantly by any dose of paclobutrazol in first year of the application. In contrary to these findings, Wood (1984); Kulkarni (1988) \& Khader (1990) reported that paclobutrazol significantly reduced the tree height, tree girth and tree spread in mango. Shoot length and leaf area were significantly affected by different doses of 
paclobutrazol. Average minimum shoot length $\left(16.53 \mathrm{~cm}\right.$ ) is obtained in $\mathrm{T}_{6}$ (Paclobutrazol 60 $\mathrm{ml} /$ tree) and maximum $(20.33 \mathrm{~cm})$ in control (without paclobutrazol).

Different doses of paclobutrazol affected the mean leaf area of Dashehari mango. Minimum leaf area was recorded under treatment $\mathrm{T}_{6}$ (paclobutrazol 60ml/tree) and maximum under control (without paclobutrazol). All treatment means having significantly less leaf area in comparison to control. This reduction in shoot length and leaf area has been due to antagonism of gibberellin biosynthesis for which paclobutrazol is known. There is considerable evidence to show that the cultar reduces vegetative growth, shoot elongation and number of leaves in many fruit trees by interrupting gibberellic acid synthesis at kaurene stage (Burondkar \& Gunjate 1991). The similar results were reported by other workers in mango (Sarkar et al. 1998; Ram et al. 2005 \& Raj Kumar et al. 2007).

Number of male flowers, hermaphrodite flowers and sex ratio significantly affected by different concentrations of paclobutrazol. Maximum male flowers were observed in treatment $T_{7}$ \{paclobutrazol $30 \mathrm{ml}(\mathrm{ES}) /$ tree $\}$ and lowest number of male flowers recorded in the treatment of paclobutrazol $20 \mathrm{ml} /$ tree $\left(\mathrm{T}_{2}\right)$ while, the number of hermaphrodite flowers were maximum in the treatment $\mathrm{T}_{4}$ (paclobutrazol $30 \mathrm{ml} /$ tree). The sex ratio was recorded highest $(1: 2.38)$ in $\mathrm{T}_{1}$ (paclobutrazol $15 \mathrm{ml} /$ tree) and lowest under control $(1: 2.85)$ followed by $\mathrm{T}_{7}$ (1:3.47). Decrease in sex ratio was observed by application of different doses of paclobutrazol. Decrease in sex ratio was due to decrease in number of male flowers and increase in sex ratio by increasing the hermaphrodite flowers. Similar findings were also reported by Singh et al. (2005) and Sarkar et al. (1998). Kurian \& Iyer (1993) reported that decrease in sex ratio due to paclobutrazol and cycocel applications when 300 random flowers per panicle were counted rather than total number of flowers.

Data in table 2 revealed that number of fruits per panicle at pea stage, fruit drop and fruit retention were significantly affected by different doses of paclobutrazol. Maximum number of fruits per panicle (48.86) at pea stage recorded in the trees treated with paclobutrazol $30 \mathrm{ml} /$ tree $\left(\mathrm{T}_{4}\right)$. The percentage of fruit drop was maximum $(97.64 \%)$ in control trees and minimum $(95.22 \%)$ in the trees treated with $30 \mathrm{ml}$ paclobutrazol/tree $\left(\mathrm{T}_{4}\right)$. Similarly the fruit retention was maximum $(4.74 \%)$ under the treatment of paclobutrazol $30 \mathrm{ml} /$ tree $\left(\mathrm{T}_{4}\right)$ and minimum $(2.35 \%)$ in the control trees.

Higher number of fruit set per panicle and more fruit retention could be due to retardation of vegetative growth and accumulation of more carbohydrates in leaves by application of paclobutrazol. Similarly more fruit retention and decreased fruit drop in paclobutrazol treated trees were also reported by Singh \& Ranganath (2002). There is a correlation between fruit drop and endogenous auxin level and existence of high level of internal auxin like substances prevent fruit drop. Exogenous application of growth regulator might help in building up endogenous level of hormone at optimal level favourable for reduction of fruit drop and increase the fruit retention.

Number of fruits per panicle, number of fruits per tree at harvest and fruit yield per tree is significantly affected by various doses of paclobutrazol over control. 
Table 1. Effect of paclobutrazol from new source on tree height, tree girth, tree spread, shoot length, leaf area, panicle length, flowering period, no. of male flower per panicle, no. of hermaphrodite flower per panicle and sex ratio of mango cv. Dashehari.

\begin{tabular}{|c|c|c|c|c|c|c|c|c|c|c|c|}
\hline \multirow[t]{2}{*}{ Treatment } & \multirow{2}{*}{$\begin{array}{c}\text { Tree } \\
\text { height } \\
(\mathrm{m})\end{array}$} & \multirow{2}{*}{$\begin{array}{l}\text { Tree } \\
\text { girth } \\
(\mathrm{m})\end{array}$} & \multicolumn{2}{|c|}{$\begin{array}{l}\text { Tree spread } \\
(\mathrm{m})\end{array}$} & \multirow{2}{*}{$\begin{array}{l}\text { Avg. } \\
\text { shoot } \\
\text { length } \\
(\mathrm{cm})\end{array}$} & \multirow{2}{*}{$\begin{array}{l}\text { Avg. } \\
\text { leaf } \\
\text { area } \\
\left(\mathrm{cm}^{2}\right)\end{array}$} & \multirow{2}{*}{$\begin{array}{l}\text { Avg. } \\
\text { panicle } \\
\text { length } \\
(\mathrm{cm})\end{array}$} & \multirow{2}{*}{$\begin{array}{l}\text { Avg. } \\
\text { flowering } \\
\text { period } \\
\text { (days) }\end{array}$} & \multirow{2}{*}{$\begin{array}{l}\text { No. of } \\
\text { male } \\
\text { flower/ } \\
\text { panicle }\end{array}$} & \multirow{2}{*}{$\begin{array}{l}\text { Hermaphrod } \\
\text { ite flower / } \\
\text { panicle }\end{array}$} & \multirow{2}{*}{$\begin{array}{c}\text { sex ratio } \\
\text { (Hermaphro } \\
\text { dite: male) }\end{array}$} \\
\hline & & & $(\mathrm{N}-\mathrm{S})$ & $(\mathrm{E}-\mathrm{W})$ & & & & & & & \\
\hline $\begin{array}{l}\text { T1:Paclobutrazo } \\
115 \mathrm{ml} / \text { tree }\end{array}$ & 5.47 & 1.04 & 8.15 & 7.87 & 19.64 & 84.65 & 25.37 & 17.80 & 864.66 & 363.00 & $1: 2.38$ \\
\hline $\begin{array}{l}\text { T2:Paclobutrazo } \\
120 \mathrm{ml} / \text { tree }\end{array}$ & 6.04 & 1.22 & 9.00 & 8.28 & 19.23 & 77.81 & 24.57 & 18.53 & 832.33 & 280.66 & $1: 2.97$ \\
\hline $\begin{array}{l}\text { T3:Paclobutrazo } \\
125 \mathrm{ml} / \text { tree }\end{array}$ & 6.33 & 1.22 & 7.94 & 7.23 & 18.50 & 77.17 & 24.04 & 19.03 & 870.66 & 356.66 & $1: 2.44$ \\
\hline $\begin{array}{l}\text { T4:Paclobutrazo } \\
130 \mathrm{ml} / \text { tree }\end{array}$ & 5.45 & 1.08 & 7.47 & 7.54 & 18.00 & 73.18 & 23.87 & 21.33 & 960.00 & 368.33 & $1: 2.62$ \\
\hline $\begin{array}{l}\text { T5:Paclobutrazo } \\
135 \mathrm{ml} / \text { tree }\end{array}$ & 5.17 & 1.03 & 7.69 & 8.16 & 17.50 & 72.90 & 22.97 & 19.43 & 1028.33 & 339.33 & $1: 3.03$ \\
\hline $\begin{array}{l}\text { T6:Paclobutrazo } \\
160 \mathrm{ml} / \text { tree }\end{array}$ & 5.57 & 0.93 & 7.34 & 7.11 & 16.53 & 67.86 & 21.70 & 18.70 & 851.33 & 287.66 & $1: 2.96$ \\
\hline $\begin{array}{l}\text { T7:Paclobutrazo } \\
130 \mathrm{ml}(\mathrm{ES}) / \text { tree }\end{array}$ & 6.06 & 0.84 & 6.18 & 6.01 & 18.37 & 73.35 & 23.14 & 19.06 & 1166.00 & 337.66 & $1: 3.47$ \\
\hline T8: Control & 5.09 & 1.12 & 8.00 & 7.73 & 20.33 & 105.00 & 26.60 & 16.63 & 972.33 & 256.000 & $1: 3.85$ \\
\hline C.D. & $\mathrm{NS}$ & $\mathrm{NS}$ & NS & NS & 0.42 & 3.80 & 0.80 & 2.22 & 79.55 & 41.87 & 0.57 \\
\hline SEm & 0.34 & 0.10 & 0.98 & 0.91 & 0.13 & 1.25 & 0.26 & 0.73 & 26.22 & 13.80 & 0.19 \\
\hline
\end{tabular}


Maximum number of fruits/ panicle (2.33) at harvest was observed in treatment of paclobutrazol $30 \mathrm{ml} /$ tree $\left(\mathrm{T}_{4}\right)$ and minimum (0.93) in control. All the doses of paclobutrazol enhanced the number of fruits per panicle significantly over control. Similarly, the number of fruits/ tree at harvest was significantly enhanced by various doses of paclobutrazol. Maximum number of fruits/tree (348.33) at harvest are recorded under the treatment $T_{4}$ (paclobutrazol $30 \mathrm{ml} /$ tree) and minimum (173.33) in control. Maximum fruit yield/ tree $(61.69 \mathrm{~kg})$ was recorded under the treatment paclobutrazol $30 \mathrm{ml}$ per tree $\left(\mathrm{T}_{4}\right)$ and minimum $(28.52 \mathrm{~kg})$ in control. The results obtained indicate that paclobutrazol dose of $30 \mathrm{ml}$ per tree $\left(T_{4}\right)$ was beneficial for enhancing the number of fruits per panicle as well as fruits per tree at harvesting and subsequently the fruit yield per tree. Similar increase in number of fruits/ panicle and yield in mango were also reported by Anbu et al (2001); Bagel et al (2004); Raj Kumar et al (2007) \& Rai \& Bist (1992). Singh \& Singh (2003) reported that more fruits per panicle, fruits/ tree and fruit yield per tree were recorded in $4 \mathrm{~g}$ a.i. treated Dashehari tree whereas $6 \mathrm{~g}$ a.i. per tree of $\mathrm{PP}_{333}$ was found more effective in cvs. Chausa \& Langra. Average fruit weight, average fruit volume and specific gravity were significantly affected by paclobutrazol. Data revealed that mean fruit weight was significantly increased over control in all the paclobutrazol treated trees with various doses. Maximum average fruit weight $(182.65 \mathrm{~g})$ was recorded in paclobutrazol $15 \mathrm{ml} /$ tree followed by $(177.0 \mathrm{~g})$ paclobutrazol $30 \mathrm{ml} /$ tree. Minimum average fruit weight $(164.66 \mathrm{~g})$ is recorded under control. The average fruit volume was also having the same trend as in case of average fruit weight. The specific gravity of the fruits treated with different doses of paclobutrazol reduced significantly over control. This increase in fruit weight might be due to increase in pulp weight of the fruit. Similar results were also observed by other workers in mango (Oosthuyse \& Jacobs 1997; Singh \& Ranganath 2006; Singh et al 2005).

There was no significant difference in average fruit length among the treatment means. However, maximum fruit length $(11.53 \mathrm{~cm})$ was recorded under the paclobutrazol $30 \mathrm{ml} /$ tree and minimum $(11.13 \mathrm{~cm})$ under treatment of paclobutrazol $60 \mathrm{ml} /$ tree. All the treatment effects were statistically at par and the similar trend have also been obtained in case of fruit diameter. Any treatment of paclobutrazol does not have any effect of fruit size. Kumar (1999) observed the similar trend in case of fruit length as affected by application of paclobutrazol in mango cultivars Dashehari, Langra, Chausa and Fazri. 
Table 2. Effect of paclobutrazol from new source on no. of fruits/panicle at pea stage, fruit drop, fruit retention, fruits per panicle at harvest, fruits/tree at harvest, yield/tree, fruit weight, fruit volume, specific gravity, fruit length and fruit diameter of mango cv. Dashehri

\begin{tabular}{|c|c|c|c|c|c|c|c|c|c|c|c|}
\hline Treatment & $\begin{array}{l}\text { No. of } \\
\text { fruits/ } \\
\text { panicle } \\
\text { at pea } \\
\text { stage }\end{array}$ & $\begin{array}{l}\text { Fruit } \\
\text { drop } \\
(\%)\end{array}$ & $\begin{array}{c}\text { Fruit } \\
\text { retention } \\
(\%)\end{array}$ & $\begin{array}{l}\text { Avg. no. of } \\
\text { fruits/ } \\
\text { panicle at } \\
\text { harvest }\end{array}$ & $\begin{array}{c}\text { Avg. no. } \\
\text { of fruits/ } \\
\text { tree at } \\
\text { harvest }\end{array}$ & $\begin{array}{l}\text { Yield/ } \\
\text { tree } \\
(\mathrm{kg})\end{array}$ & $\begin{array}{l}\text { Avg. } \\
\text { fruit } \\
\text { weight } \\
(\mathrm{g})\end{array}$ & $\begin{array}{l}\text { Avg. } \\
\text { fruit } \\
\text { volume } \\
\text { (cc.) }\end{array}$ & $\begin{array}{c}\text { Specific } \\
\text { gravity } \\
\text { (g/cc.) }\end{array}$ & $\begin{array}{l}\text { Avg. } \\
\text { fruit } \\
\text { length } \\
(\mathrm{cm})\end{array}$ & $\begin{array}{c}\text { Avg. } \\
\text { fruit } \\
\text { diameter } \\
(\mathrm{cm})\end{array}$ \\
\hline $\begin{array}{l}\text { T1:Paclobutrazol } \\
15 \mathrm{ml} / \text { tree }\end{array}$ & 42.41 & 96.77 & 3.22 & 1.36 & 185.00 & 33.80 & 182.65 & 179.33 & 1.018 & 11.40 & 5.53 \\
\hline $\begin{array}{l}\text { T2:Paclobutrazol } \\
20 \mathrm{ml} / \text { tree }\end{array}$ & 45.73 & 96.43 & 3.56 & 1.63 & 225.00 & 38.60 & 171.66 & 168.32 & 1.019 & 11.33 & 5.40 \\
\hline $\begin{array}{l}\text { T3:Paclobutrazol } \\
25 \mathrm{ml} / \text { tree }\end{array}$ & 46.59 & 96.56 & 3.43 & 1.60 & 263.31 & 46.17 & 175.33 & 172.33 & 1.017 & 11.23 & 5.46 \\
\hline $\begin{array}{l}\text { T4:Paclobutrazol } \\
30 \mathrm{ml} / \text { tree }\end{array}$ & 48.86 & 95.22 & 4.74 & 2.33 & 348.33 & 61.69 & 177.00 & 175.34 & 1.009 & 11.53 & 5.66 \\
\hline $\begin{array}{l}\text { T5:Paclobutrazol } \\
35 \mathrm{ml} / \text { tree }\end{array}$ & 46.57 & 96.27 & 3.72 & 1.73 & 291.64 & 50.97 & 174.64 & 173.00 & 1.009 & 11.23 & 5.36 \\
\hline $\begin{array}{l}\text { T6:Paclobutrazol } \\
60 \mathrm{ml} / \text { tree }\end{array}$ & 45.35 & 96.54 & 3.45 & 1.56 & 261.66 & 44.38 & 169.66 & 167.33 & 1.013 & 11.13 & 5.30 \\
\hline $\begin{array}{l}\text { T7:Paclobutrazol } \\
30 \mathrm{ml}(\mathrm{ES}) / \text { tree }\end{array}$ & 45.66 & 96.13 & 3.86 & 1.76 & 268.32 & 45.52 & 169.65 & 166.66 & 1.018 & 11.36 & 5.40 \\
\hline T8: Control & 39.55 & 97.64 & 2.35 & 0.93 & 173.33 & 28.52 & 164.66 & 160.00 & 1.029 & 11.23 & 5.43 \\
\hline C.D. at $5 \%$ & 0.40 & 0.80 & 0.80 & 0.36 & 28.41 & 5.12 & 4.39 & 3.67 & 0.009 & NS & NS \\
\hline Sem & 0.13 & 0.26 & 0.26 & 0.12 & 9.36 & 1.69 & 1.45 & 1.21 & 0.003 & 0.23 & 0.12 \\
\hline
\end{tabular}


Peel weight, pulp weight, stone weight and peel, pulp, stone ratio (Table 3) showed that except pulp weight remaining characters were not affected by any of the dose of paclobutrazol. The mean peel weight was maximum $(23.63 \mathrm{~g})$ under the treatment paclobutrazol $15 \mathrm{ml} /$ tree and minimum (16.76g) in control. Maximum pulp weight (140.0g) was observed under the treatment of paclobutrazol $15 \mathrm{ml} /$ tree. The pulp weigh was increased in all the treatments over control. Mean stone weight was not significantly affected by any of the dose of paclobutrazol. However, maximum stone weight $(25.40 \mathrm{~g})$ was recorded under treatment of paclobutrazol $35 \mathrm{ml} /$ tree and minimum $(18.0 \mathrm{~g})$ in treatment $\mathrm{T}_{2}$ (paclobutrazol $20 \mathrm{ml} /$ tree). Peel, pulp and stone ratio was not significantly affected by any of the dose of paclobutrazol. However, lesser ratio $(1: 7: 1)$ was observed in treatment $\mathrm{T}_{5}$ (paclobutrazol $35 \mathrm{ml} /$ tree). This increase in pulp weight might be due to increase in weight of the fruits. Similar findings were also reported by Desai \& Chundawat (1994); Singh et al (1998) in mango. The percentage of acidity of the fruit was significantly affected by the different doses of paclobutrazol. The maximum acidity $(0.25 \%)$ was recorded under the fruit of control trees, while the lowest acidity $(0.11 \%)$ recorded in treatments $T_{4}$ (paclobutrazol 30ml/tree), $\mathrm{T}_{5}$ (paclobutrazol $35 \mathrm{ml} /$ tree) and $\mathrm{T}_{7}$ \{paclobutrazol $30 \mathrm{ml}$ (ES)/ tree\}. All the treatments except control are statistically at par. The TSS of the fruit was also significantly enhanced over control in different treatments of paclobutrazol.

The TSS of treatment $\mathrm{T}_{1}, \mathrm{~T}_{2} \& \mathrm{~T}_{8}$ are statistically at par while others are significant over these treatments $\left(T_{1}, T_{2}\right.$ and $\left.T_{8}\right)$. The enhancement of TSS and reduction in acidity in fruits might be due to rapid hydrolysis of polysaccharides into soluble sugars and also due to increased mobilization of carbohydrates from the source to sink under the influence of paclobutrazol. These results are also in conformity with Vijaylakshmi \& Srinivasan (2000); Singh \& Ranganath (2006). Rath \& Rajput (1990); Vijaylakshmi \& Srinivasan (2000) concluded that maximum reduction of acidity in fruits was caused by $\mathrm{PP}_{333}$ (7.5g and $5.0 \mathrm{~g})$ application.

Data recorded (Table 3) on total sugar and reducing sugar were significantly affected by the paclobutrazol doses, while nonreducing sugar content was non-significant among the treatments of paclobutrazol. Maximum total sugar $(17.51 \%)$ was found in the treatment of paclobutrazol $35 \mathrm{ml} /$ tree followed by paclobutrazol $30 \mathrm{ml} /$ tree and they were statistically at par to each other. Minimum total sugar $(16.44 \%)$ was recorded in control trees fruits. Reducing sugar was observed maximum $(3.81 \%)$ under treatment of paclobutrazol $30 \mathrm{ml} /$ tree $\left(\mathrm{T}_{4}\right)$ followed by paclobutrazol $35 \mathrm{ml} /$ tree $(3.76 \%)$ while, other treatments enhanced the reducing sugar significantly over control. The non-reducing sugar was found maximum $(13.74 \%)$ under $T_{5}$ followed by $\mathrm{T}_{4}$ but there is no significant difference among treatment means with any dose of paclobutrazol. Such increase in sugar content by paclobutrazol application might be due to rapid translocation of sugars in larger amounts towards fruit and rapid conversion of starch into sugars. 
Table 3. Effect of paclobutrazol from new source on peel weight, pulp weight, stone weight, their ratio, titrable acidity, TSS , total sugar, reducing sugar non-reducing sugar, ascorbic acid and $\beta$ carotene on mango cv. Dashehari

\begin{tabular}{|c|c|c|c|c|c|c|c|c|c|c|c|}
\hline Treatment & $\begin{array}{l}\text { Avg. } \\
\text { peel } \\
\text { weight } \\
(\mathrm{g})\end{array}$ & $\begin{array}{c}\text { Avg. } \\
\text { pulp } \\
\text { weight } \\
(\mathrm{g})\end{array}$ & $\begin{array}{c}\text { Avg. } \\
\text { stone } \\
\text { weight } \\
(\mathrm{g})\end{array}$ & $\begin{array}{l}\text { Peel: } \\
\text { Pulp: } \\
\text { Stone } \\
\text { ratio }\end{array}$ & $\begin{array}{c}\text { Titrable } \\
\text { acidity } \\
(\%)\end{array}$ & $\begin{array}{l}\text { TSS } \\
(\%)\end{array}$ & $\begin{array}{c}\text { Total } \\
\text { sugar } \\
(\%)\end{array}$ & $\begin{array}{l}\text { Reducing } \\
\text { sugar } \\
(\%)\end{array}$ & $\begin{array}{l}\text { Non- } \\
\text { reducing } \\
\quad(\%)\end{array}$ & $\begin{array}{c}\text { Ascorbic } \\
\text { acid } \\
\text { (mg/100g } \\
\text { pulp) }\end{array}$ & $\begin{array}{c}\beta \\
\text { carotene } \\
(\mathrm{mg} / 100 \mathrm{~g} \\
\text { pulp })\end{array}$ \\
\hline $\begin{array}{l}\text { T1:Paclobutrazol } \\
15 \mathrm{ml} / \text { tree }\end{array}$ & 23.63 & 140.00 & 18.33 & $1.0: 8: 1.0$ & 0.18 & 17.56 & 16.58 & 3.42 & 13.16 & 14.69 & 1.30 \\
\hline $\begin{array}{l}\text { T2:Paclobutrazol } \\
20 \mathrm{ml} / \text { tree }\end{array}$ & 16.87 & 133.56 & 18.00 & $1.0: 8: 1.0$ & 0.13 & 17.53 & 16.84 & 3.49 & 13.34 & 15.15 & 1.43 \\
\hline $\begin{array}{l}\text { T3:Paclobutrazol } \\
25 \mathrm{ml} / \text { tree }\end{array}$ & 18.90 & 136.10 & 22.73 & $1.0: 8: 1.0$ & 0.12 & 18.23 & 16.96 & 3.50 & 13.46 & 15.34 & 1.48 \\
\hline $\begin{array}{l}\text { T4:Paclobutrazol } \\
30 \mathrm{ml} / \text { tree }\end{array}$ & 20.38 & 136.33 & 24.00 & $1.0: 8: 1.0$ & 0.11 & 19.50 & 17.28 & 3.81 & 13.47 & 16.56 & 1.49 \\
\hline $\begin{array}{l}\text { T5:Paclobutrazol } \\
35 \mathrm{ml} / \text { tree }\end{array}$ & 20.37 & 137.00 & 25.40 & $1.0: 7: 1.0$ & 0.11 & 19.43 & 17.51 & 3.76 & 13.74 & 16.45 & 1.54 \\
\hline $\begin{array}{l}\text { T6:Paclobutrazol } \\
60 \mathrm{ml} / \text { tree }\end{array}$ & 18.62 & 128.33 & 23.10 & 1.0:8:1.0 & 0.12 & 18.53 & 16.59 & 3.53 & 13.06 & 16.23 & 1.55 \\
\hline $\begin{array}{l}\text { T7:Paclobutrazol } \\
30 \mathrm{ml}(\mathrm{ES}) / \text { tree }\end{array}$ & 16.91 & 132.33 & 22.10 & $1.0: 8: 1.0$ & 0.11 & 18.20 & 16.56 & 3.59 & 12.97 & 14.55 & 1.58 \\
\hline T8: Control & 16.76 & 123.33 & 19.00 & $1.0: 8: 1.0$ & 0.25 & 17.36 & 16.44 & 3.30 & 13.13 & 14.43 & 1.38 \\
\hline C.D. at $5 \%$ & NS & 25.34 & NS & NS & 0.05 & 0.44 & 0.57 & 0.07 & NS & 0.58 & 0.18 \\
\hline Sem & 2.18 & 8.35 & 3.56 & 10.29 & 0.017 & 0.14 & 0.18 & 0.025 & 0.18 & 0.19 & 0.59 \\
\hline
\end{tabular}


These results are in conformity with the reports of Rath \& Rajput (1990); Vijaylakshmi \& Srinivasan (2000). Maximum ascorbic acid (16.56 mg/100g) content was found in treatment of paclobutrazol $30 \mathrm{ml} /$ tree followed by paclobutrazol $35 \mathrm{ml} /$ tree $\left(\mathrm{T}_{5}\right)$ and minimum $(14.43 \mathrm{mg} / 100 \mathrm{~g})$ in control trees fruits. $\beta$ carotene content was maximum (1.58 $\mathrm{mg} / 100 \mathrm{~g}$ pulp) under paclobutrazol $\mathrm{T}_{7}$ \{paclobutrazol 30ml (ES)/ tree\} followed by paclobutrazol $60 \mathrm{ml} /$ tree (T6) and minimum $(1.30 \mathrm{mg} / 100 \mathrm{~g}$ pulp) in paclobutrazol $15 \mathrm{ml} /$ tree (T1). These findings are also in conformity with the results of Khadar (1990). Singh \& Ram (1998) reported that application of paclobutrazol increased ascorbic acid and carotene contents of mango fruit.

On the basis of results summarized above, it can be concluded that there was significant variations in growth, flowering and yield attributes due to different doses of paclobutrazol. However, treatment $\mathrm{T}_{4}$ (paclobutrazol $30 \mathrm{ml} /$ tree) was found significant with respect to most of the vegetative, flowering, yield and physicochemical attributes. Therefore, it is finally concluded that paclobutrazol @ $30 \mathrm{ml} /$ tree should be applied for getting maximum fruit yield without affecting the fruit quality.

\section{References}

Anbu S, Parthiban S, Rajangam J \& Thangaraj T. 2001. Induction of off season flowering in mango (Mangifera indica L.) using paclobutrazol. South Indian Horticulture, 49(Special): 384-385.

Anusuya R, Vijayakumar RM, Srividhya S \& Sivakumar R. 2018. Comparison of physiological and flowering parameters of main and off season by using different plant nutrients and growth hormone in mango (Mangifera indica L.) cv. Bangalora. Journal of Agriculture and Ecology, 5: 76-82.

Bagel BS, Tiwari R, and Gupta N. 2004. Effect of cultar and NAA on flowering and fruiting of mango (Mangifera indica L.) cv. Langra. South Indien Horticulture, 52(1/6): 302-304.

Burondkar MM \& Gunjate RT.1991. Regulation of shoot growth and flowering in Alphonso mango with paclobutrazol. Acta Horticulture, 291: 79-82.

Gora JS, Singh VK, Sarolia DK, Kumar K, Rajkumar \& Bhati V. 2017. Performance of mango (Mangifera indica L.) monoembryonic and polyembryonic seedlings under salt stress condition. International Journal of Current Microbiology and Applied Science, 6(6): 3051-3056.

Khader, SESA.1990. Control of tree height, trunk girth, shoot growth and total assimilation in young grafted mango tree by paclobutrazol. Indian Journal of of Horticulture, 48: 112-115.

Kulkarni VJ.1998. Chemical control of tree vigor and the promotion of flowering and fruiting in mango (Mangifera indica L.) using paclobutrazol. Journal of Horticulture Science, 63: 557-566.

Kumar A.1999. Effect of paclobutrazol on growth, flowering, fruiting and yield of Mango cultivars. Thesis, Doctor of Phylosophy (Horticulture) G.B. Pant University of Agriculture and Technology, Pantnagar.

Kumar K, Srivastav M, Singh SK \& Vinod 2016. Ascertaining hybridity of progenies in mango (Mangifera indica L.) using microsatellite (SSR) markers. Journal of Agriculture and Ecology, 2: 1-10. 
Kumar K. 2015. DNA marker-based differentiation of zygotic and nucellar seedlings and identification of polymorphic microsatellite markers among parental mango genotypes. Thesis, Doctor of Phylosophy (Horticulture) submitted to ICARIndian Agricultural Research Institute, Pusa, New Delhi.

Kurian RM \& Iyer CPA.1993. Chemical regulation of tree size in mango (Mangifera indica L.) cv. Alphonso. II. Effects of growth retardants on flowering and fruit set. Journal of Horticulture Science, 68(3): 355-360.

Narvariya SS, Dhami V, Singh CP \& Kumar K.2015. Efficacy of Cultar on growth, flowering and yield behavior of mango (Mangifera indica L.) cv Dashehari. Environmental Ecology, 33(2A): 827831.

Oosthuyse SA \& Jacobs G.1997. Effect of soil applied paclobutrazol on fruit retention, fruit size, tree yield and tree revenue in Sensation and Tommy Atkins mango. South African Mango Growers' Association Yearbook, Vol.17, 57-62.

Pandey SN \& Dinesh MR.2010. Mango, Indian Council of Agricultural Research, New Delhi. p 30, 97.

Rai N \& Bist LD.1992. Effect of soil and foliar applied paclobutrazol on vegetative growth, flowering, fruit set and yield of oriental pear (Pyrus pyrifolia (Burm) nakai). Scientia Hortulture, 50: 153-158.

Rajkumar M, Reddy YN, Chandrasekhar R \& Srihari D.2007. Studies on the effect of foliar application of chemicals and groth regulators on the fruit yield of unpruned mango (Mangifera indica L.) trees cv. Baneshan. The Orissa Journal of Horticulture, 3, 2: 44-47.
Ram RB, Vismil RS \& Lal B.2005. Effect of pruning severities and paclobutrazol on bearing behaviour of rejuvenated mango trees cv. Dashehari. New Agriculturist, $16: 1 / 2,1-9$.

Sarkar SK, Gautham B, Srihari D \& Seethambaram Y.1998. Regulation of tree vigour in mango. Indian Journal of Horticulture, 55,1: 37-41.

Singh DB \& Ranganath HR.2006. Induction of regular and early fruiting in mango by paclobutrazol under tropical humid climate. Indian Journal of Horticulture, 63: 248-249.

Singh DK, Ram S.1998. Effect of time of paclobutrazol application on fruit quality of mango. Indian Agriculturist, 42: 121126.

Singh NP, Malhi CS \& Sharma RC.2005. Effect of plant bio regulators (PBRs) on flowering, fruit yield and quality in mango cv. Dashehari. HorticulturalJournal, 18(1):10-12.

Singh VK \& Singh A.2003. Effect of paclobutrazol on regularity of bearing in mango (Mangifera indica L.). Physiollogy, Molecular and Biology of Plants 9(2): 239-248.

Vijaylakshmi D \& Srinivasan PL.2000. Improving the quality attributes of 'off' year Alphonso mango through chemicals and growth regulators. The Orissa Journal of Horticulture, 28(1):31-33.

Wood BW.1984. Influence of paclobutrazol on selected growth and chemical characteristics of young pecan seedlings. Horticulture Science, 19: 837-839. 